\title{
Abnormal Succession of Insect Fauna on Pig Carcasses in Tandil (Argentina, Buenos Aires Province)
}

\author{
A. Verónica Trigo, Néstor Centeno \\ Laboratorio de Entomología Aplicada y Forense, Departamento de Ciencia y Tecnología, Universidad Nacional \\ de Quilmes, Bernal, Argentina \\ Email: forensictrigo@yahoo.com.ar, ncenteno@unq.edu.ar
}

Received 30 January 2014; revised 16 March 2014; accepted 22 March 2014

Copyright (C) 2014 by authors and Scientific Research Publishing Inc.

This work is licensed under the Creative Commons Attribution International License (CC BY). http://creativecommons.org/licenses/by/4.0/

c) (7) Open Access

\begin{abstract}
This project was an attempt to reconstruct a death in dubious circumstance which happened in December 2002 in Tandil (Buenos Aires Province). Although the body was in open air, the entomological expertise discovered signs of delayed colonization. In this experiment, pig carcasses used as models to reconstruct the case. One was placed in shadow and another in sunlight (control). The hypothesis was that the climate and the topography affect the necrophagous insect succession in a mountain site. The families of Coleoptera found on the baits were: Silphidae, Dermestidae, Cleridae, Histeridae; of Díptera: Calliphoridae, Sarcophagidae; Asilidae; of Hymenoptera: Formicidae, Encyrtidae and Vespidae.
\end{abstract}

Keywords

Forensic Entomology, Calliphoridae, Tandil

\section{Introduction}

\subsection{General}

The dead body of an animal (or human being) is a temporary, progressively changing microhabitat which provides food resources for a broad range of organisms [1]. During most stages of decay, immature individuals predominate. Species exploiting this ephemeral type of habitat are adapted as a rule to feed rapidly in the larval stages and to leave the substrate for metamorphosis to the next life stage (adult).

The time elapsed between death and the arrival of the first Arthropoda depends on the species ("species-specific"). It also depends on the microhabitat in which the corpse [2] is placed. Colonization is governed 
both by autogenic (production of scents attractive to insects, resign of temperature by decomposition) and allogenic (mainly ambient temperature, humidity, rain and abundance of insects) factors [3] [4]. Allogenic factors are affected by seasonality, especially in temperate zones [5].

Terpenoids are the unsaturated hydrocarbons; it was found in needles, stems, and roots of conifers like Eucaliptus sp.; especially monoterpenoids, have a wide range of effects on host insect relationships, resin biosynthesis, feeding deterrence, response to wounding, chemical cues for aggregation of pheromones and kairomone range, and insect fecundity. On the other hand, some degree of eucalyptol toxicity has been shown in some medically and/or economically important insects [6].

The entomology evidence is a powerful tool in the criminal investigation, providing that the whole evidence is available. This allows an appropriate interpretation of the circumstances that surrounded the death, as well as of the time lapsed from the death, contributing valuable information in this way to the judicial investigation. A fact that the provincial courts rarely think of giving to the consulted expert is the type of local climate and the meteorological conditions that reigned in the precedent days to the discovery of the corpse [7].

\subsection{The Case}

In December 2002, a dead body was found at the foot of a crag called Cerro La Movediza, which is the natural pedestal of a "teetesing rock" which fell some time ago after being a touristic attraction for a long time. The "pedestal" presents a flatish top, worn smooth in parts because of the oscillation of the "teetesing rock", and sloping outwardly in the few decimeters at the edge. A person standing at the very brink would tend to slip and would be in risk of falling down the crag. It is known as well that high points commanding a view have a strong attraction both for people with suicidal ideas and for persons under the influence of drugs [8] [9]. The slope where the person would fall is the southern one; in the southern hemisphere, this means that it does not receive the sun. There are several high blocks of stone that would assist in blocking the sunlight from corpse.

Deceased was a 25 - 35 years old male, 75 - $80 \mathrm{~kg}$ in weight, $168 \mathrm{~cm}$ in stature. The body was entirely unclothed and lying Decubitus-Dorsal position. It was lying in a space surrounded by large boulders. What was remarkable about this body was that it was beginning to be colonized by the Calliphorid fly Cochliomyia macellaria, a species which in the city of Buenos Aires is associated with indoor corpses [10]. As exposition to light had occurred on a south-facing hillside and among large boulders, the presence of $C$. macellaria was thought to be caused by deep shadow, and it was not taken to indicate a concealment of the body in the first few days after death, as it has happened in other cases.

\subsection{Reconstruction}

The present experiment aimed at establishing whether a corpse lying outdoors in Tandil could be colonized by the fauna associated with indoor corpse (especially C. macellaria) if left in shadow. The following hypotheses were proposed: $\mathrm{H} 1$ = that the mountain climate (low humidity, large diel fluctuation of temperature) would influence the succession of corpse fauna [11]; H2 = that the carcass in shadow would present a retarded colonization in comparison to the control set in sunlight; $\mathrm{H3}=$ that the shadowed carcass would repeat the results of the forensic case described above.

\subsection{The Site}

The experiment was carried out in a semirural area in Tandil, Buenos Aires province, Argentina $\left(37^{\circ} 14^{\prime} \mathrm{S}\right.$; $59^{\circ} 15^{\prime} \mathrm{W}$; average altitude $175 \mathrm{~m}$ above sea level). This locality is in the southeast of Buenos Aires province. From the phytogeografic point of view, it corresponds to the peri-steppe Espinal, more precisely to the SW of the Central district (Platense sub-district). Towards the southern end there is some admixture of the Pterophytic district [12]. The climate is a sub-humid mountain climate. The average temperature is $14^{\circ} \mathrm{C}$; the average maximum is $20^{\circ} \mathrm{C}$ (highest records in January) and the minimal is around $8^{\circ} \mathrm{C}$ (June, July and August). Average annual precipitation is $800 \mathrm{~mm}$.

The field where the experiment was carried out belongs to the Faculty of Veterinary Science of the Universidad del Centro (UC). It lies on an easy slope, with a small brook running through the end closer to the road, while the other end rises considerably above the latter. Further up the slope moderately steep; on the other side of the hilltop there is a nearly sheer slope, much used for the practice of "abselling". 
There is a single tree in the field, a specimen of Eucalyptus camaldulensis (Myrtaceae). The ground is covered with various grasses (Poacee) and with clumps of pennyroyal (Mentha pulegium; Lamiaceae). Most of the flora is introduced, save for the water-plants in the brook. We observed, however, several clumps of the autochthonous "camambú" (Physalis viscosa; Solanaceae).

The field was being used to graze three horses (a large-size Breton stallion and two Criollo mix geldings) and six male llamas (Lama lama; Auchenidae).

Vertebrate scavengers in the area include domestic dogs, foxes, rodents, several species of Falconidae, and notably armadillos (Edentata: Dasypodidae).

\section{Materials and Methods}

Two domestic pig carcasses were used as models. The pigs were killed by cardiac puncture. The pigs were killed by the supplier at 9:00 hs and placed in garbage bags hermetically sealed for transportation.

Cages of woven wire reinforced with wood dowels were used to protect the carcasses from scavenging vertebrate. Some modifications were made to the protocol suggested by Goff [1]. Because there were large quadruped1 loose in the field used for the experiment. The cages were fixed to the ground with stout stakes of the type used for barbed wire fences, and only the top came off.

The shadow was given for an individual of Eucalyptus camaldulensis, it is known that vegatal species produces and liberates in the air considerable quantities of volatile compounds, of which the main ones are: 1,8cineol (eucalipthol)-pinene-pinene and terpineol [13] [14].

The volatile compounds of the eucalyptus, as well as those of other vegetal species, extend though the air occupying a bell-shaped space, the form and position of which vary according to the speed and direction of the wind (Quesada-Allué, personal communication). This suggests the interesting possibility that only in certain moments the combination of variables has allowed Diptera to perceive the scent of the carcass.

One carcass was set on a small irregular slope, under a specimen of Eucalyptus camaldulensis which provided the sole shadowed place in the field; the control was set in the sunlight in a flat place.

The pig that was placed in the sun weighed $12.200 \mathrm{~kg}$ and it was placed in the cage at 10:05 hs. The control pig weighed $12.2 \mathrm{~kg}$, the shadowed one $14.35 \mathrm{~kg}$ and it was located in the cage 10:15 a.m.

Each carcass was examined at least twice a day during the first 7 day, and once a day from the $8^{\text {th }}$ to $14^{\text {th }}$ days. They were rotated for sampling and examining and then left again in the original position.

From each lot of collected larvae, half were fixed with water at $95^{\circ} \mathrm{C}$ and kept in ethanol $70 \%$, and the other half taken to the laboratory to rear. Samples from different parts of the body were kept separate.

The duration of the experiment had been fixed as the time needed by the sunlit carcass (control) for total reduction, which was completed in sixteen days, specifically between February $14^{\text {th }}$ and March $1^{\text {rst }}$. The duration of the experiment had been set as the time needed by the body illuminated by the sun (control) to the total reduction, which was completed in sixteen specific days between February 14 to March 1, in these sixteen days varied from sunny to cloudy and windy weather with little wind.

During the course of the experiment were able to identify the following states of decomposition:

Fresh from the moment of the death until abdominal distension becomes evident. The first insects that arrive to the carcass are flies of the families Calliphoridae and Sarcophagidae that deposit their eggs or larvae, according to the family, in the natural openings of the head and genito-anal area, as well as in wounds if any (Figure 2 and Figure 3).

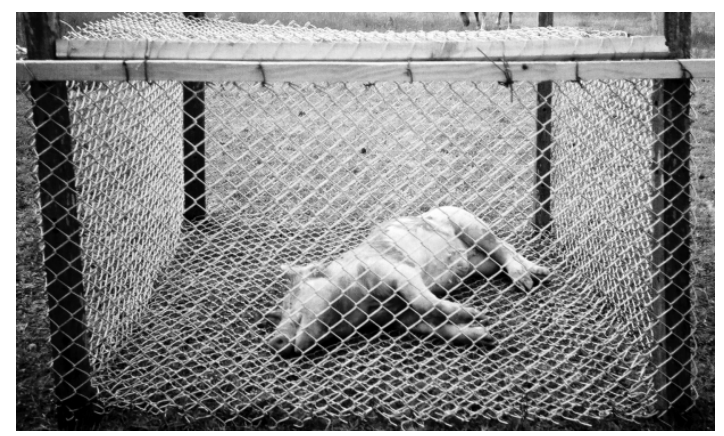

Figure 2. Fresh sunlit. 
Bloated: abdomen swollen by the gases produced by metabolic activities of the anaerobic bacteria. Calliphoridae adults show a strong attraction for this stage (Figure 4 and Figure 5).

Active decay: the skin breaks, allowing the gases to escape. The masses of Diptera larvae are the most important element, as well as the adults and grubs of Coleoptera (Staphylinidae, Histeridae); in the last stage large numbers of necrophages and necrophyles are observed (Figures 6-9).

Skeletal reduction: bones and hair. Presence of acari in the ground. The variations of the fauna of ground can be detected after months or even years, depending on the local conditions [1] (Figure 10 and Figure 11).

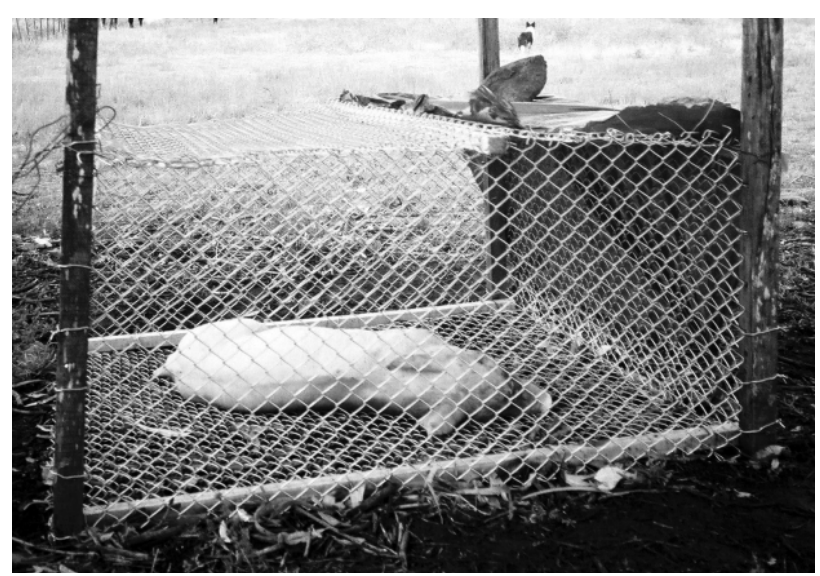

Figure 3. Fresh shadowed.

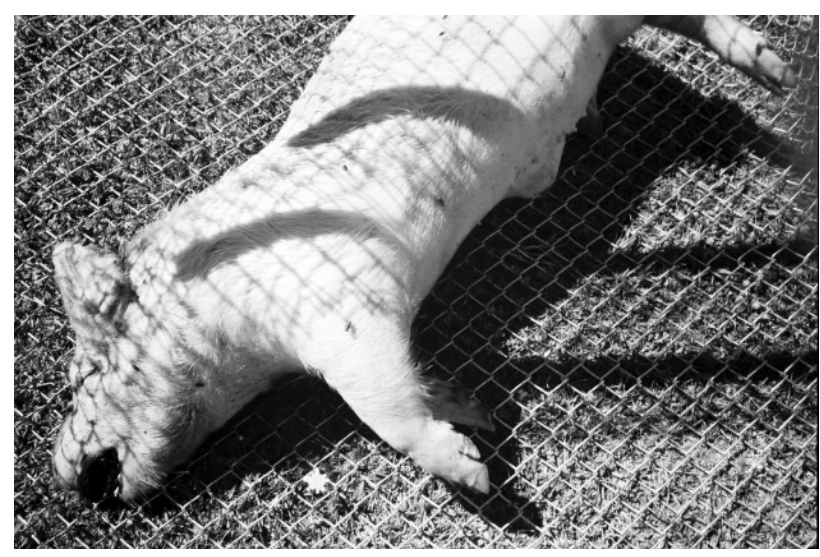

Figure 4. Bloated sunlit

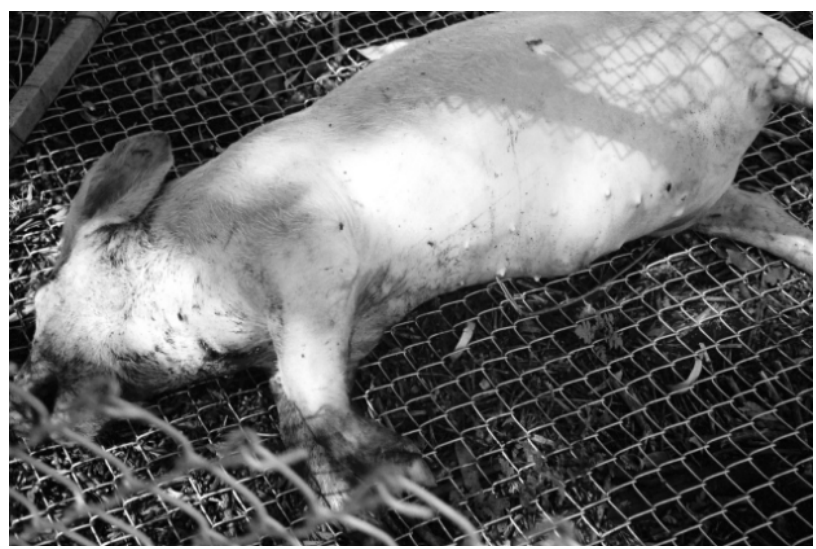

Figure 5. Bloated shadowed. 


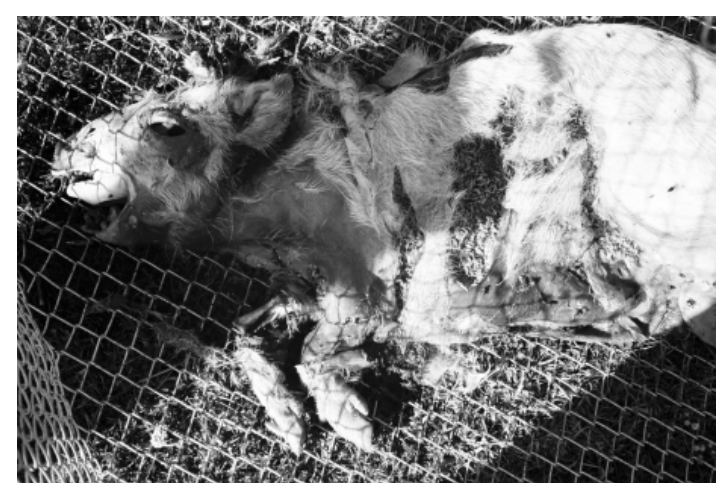

Figure 6. Active decay sunlit.

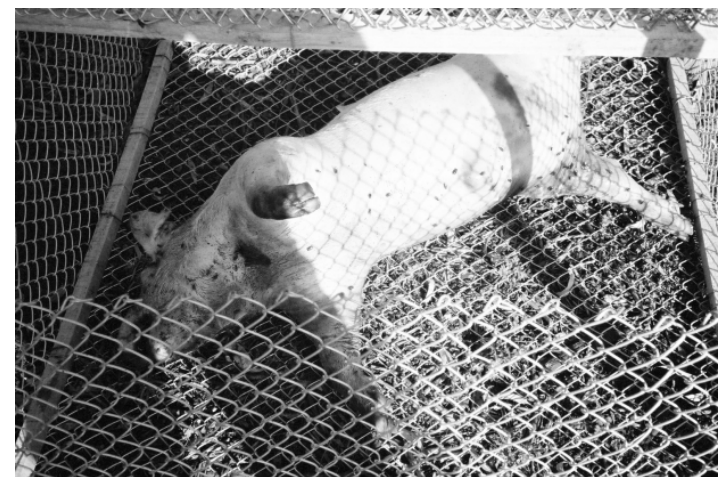

Figure 7. Bloated shadowed.

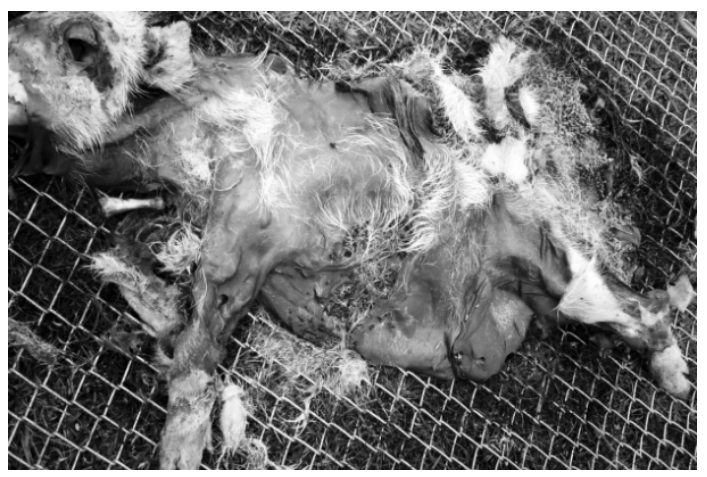

Figure 8. Active decay sunlit.

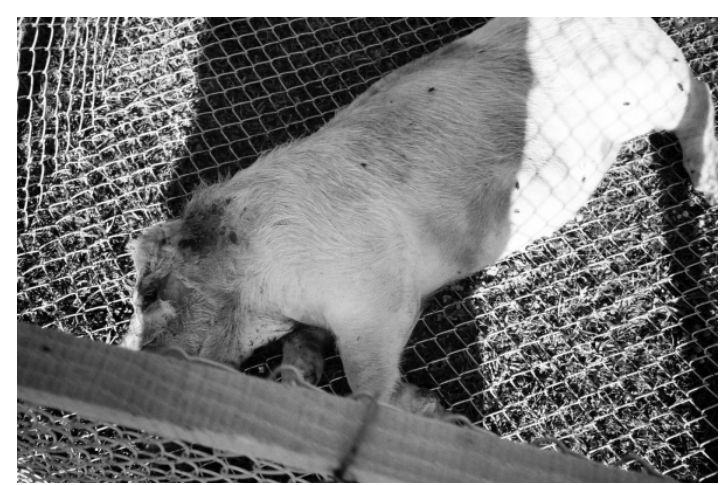

Figure 9. Low decay shadowed. 


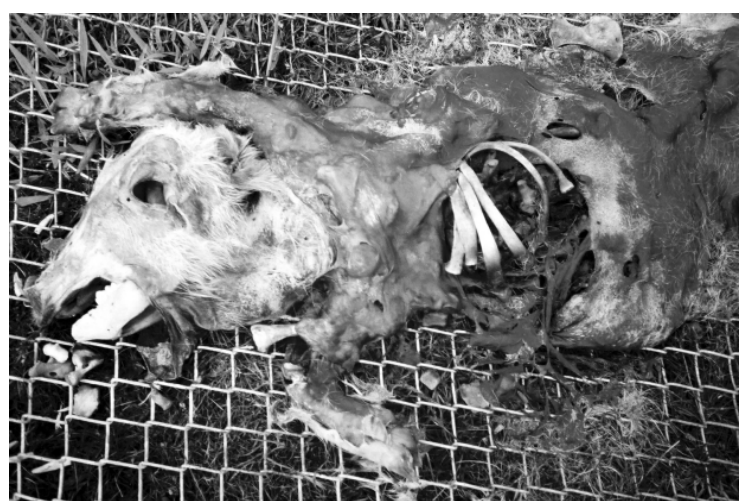

Figure 10. skeletal reduction sunlit.

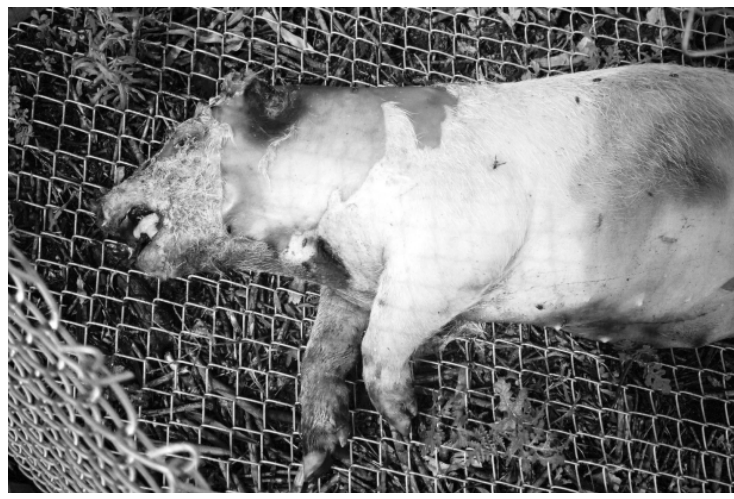

Figure 11. Low decay shadowed.

\section{Taxonomic}

The determination of the samples was carried out in the laboratory of forensic entomology in Museo Argentino de Ciencias Naturales (MACN) with the keys in Greenberg \& Szyska [15], Liu \& Greenberg [16], Mariluis \& Schnack [17] and Oliva [18]. A Zeiss steromicroscope with magnification up to 50× was used. Pictures were taken with a Nikon DXF 1200 camera, mounted as need a on a Nikon C-PS 160 stereomicroscope.

\section{Results}

After the determination of the material collected are: four families of the order Coleoptera (Oxelytrum erythrurum (Blanchard, 1840), Dermestes maculatus DeGeer, 1774, Necrobia rufipes DeGreer, 1775 y Saprinus sp.); four families of the order Diptera (Hydrotaea sp.; Sarcophaga sp.; Phaenicia sericata (Meigen, 1826); Sarconesia chlorogaster (Wiedemann, 1818); Consomyiops fulvicrura (Robineau-Desvoidy, 1830); Paralucilia pseudolyrcea (Mello, 1969); Chrysomya albiceps (Wiedemann, 1819); Cochliomyia macellaria (Fabricius, 1775); Mallophora sp.) and finally three families of the order Hymenoptera (Solenopsis sp. Polybia sp. (cf. scutellaris); Tachinaephagus zealandicus Ashmead, 1904).

Can see in the Tables 1-3 relate data of the order of arrival of the species on to the carcasses, with the or the stages of decomposition in which those species appear under each experimental conditions (sunlit and shadowed).

It lists of species, instars found in each of the decomposition for each pig Table 1—Sunlit-; Table 2—Shadow A: adult, L: maggots and Table 3: summarizes the species found in each stage of the decomposition both sunlit and shadow

In the present experiment, Diptera were first to arrive; Coleoptera didn't appear before the day 9 of the experiment (February 23) for the sunlit carcass and day 13 for the shadowed one (Figure 1).

\subsection{Diversty}

Diptera: Calliphoridae: Cochliomyia macellaria, Phaenicia sericata, Consomyops fulvicrura, Chrysomya albi- 
ceps, Paralucilia pseudolyrcea (in order of abundance). Sarcophagidae: Sarcophaga sp. Muscidae: Hydrotaea sp. (Figure 1).

Cochliomyia macellaria [19] was the main colonizer in this experiment (as well as in the reconstructed forensic case). Although attracted to the pigs once these had entered in decomposition, it appeared to be a primary because the pure primary species had been displaced, due to the climatic conditions.

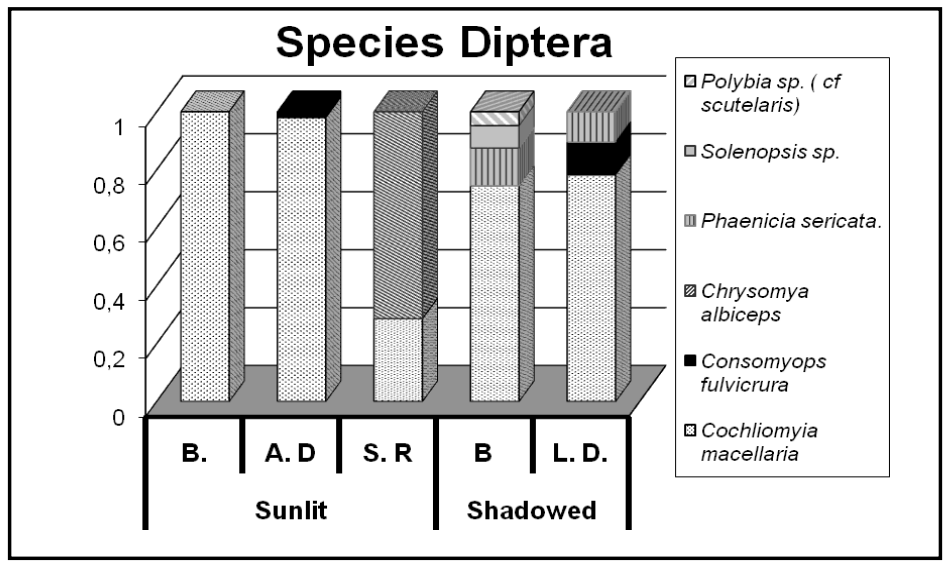

Figure 1. Species of Diptera found in sunlit and shadowed carcasses. B: Bloated; A. D.: Active Decay; S. R.: Skeletal Reduction; L. D. = Low Decay.

Table 1. Order of arrival of the species with the stages of decomposition at sunlit.

\begin{tabular}{|c|c|c|c|c|c|c|c|c|c|}
\hline & \multicolumn{9}{|c|}{ Stages of decomposition- Sunlit } \\
\hline & Fresh & Bloated & & & & ctive dec: & & & Skeketal reduction \\
\hline & 15-Feb 16-Feb 17-Feb & 18-Feb 19-Feb 20-Feb & 21-Feb & 22-Feb & 23-Feb & 24-Feb & $25-\mathrm{Feb}$ & $26-\mathrm{Feb}$ & 27-Feb $28-F e b \quad$ 01-Mar \\
\hline $\begin{array}{l}\text { Diptera } \\
\text { Phaenicia sericata } \\
\text { Cochliomya macellaria } \\
\text { Consomyops fulvicrura } \\
\text { Chrysomya albiceps } \\
\text { Ophyra / Hydrotea sp } \\
\text { Sarcophaga sp }\end{array}$ & & L1 & L2 & $\begin{array}{c}\text { A } \\
\text { L1; L2; } \\
\text { L3; A } \\
\text { A } \\
\text { A } \\
\text { A }\end{array}$ & $\begin{array}{l}\text { L1; L2; } \\
\text { L3 }\end{array}$ & $\begin{array}{l}\text { L1; L2; } \\
\text { L3 } \\
\text { L } 1\end{array}$ & $\begin{array}{l}\text { L3 } \\
\text { L3 }\end{array}$ & L2; L3 & $\begin{array}{l}\text { L2 } \\
\text { L3 }\end{array}$ \\
\hline $\begin{array}{l}\text { Coleoptera } \\
\text { oxyeletrun erythrura } \\
\text { Saprinus sp } \\
\text { Dermestes maculatus } \\
\text { Necrobia rufipes }\end{array}$ & & & & & $\begin{array}{l}\text { A } \\
\text { A }\end{array}$ & $\begin{array}{l}\text { A } \\
\text { A }\end{array}$ & $\begin{array}{l}\text { A } \\
\text { A }\end{array}$ & A & \\
\hline \begin{tabular}{|l|} 
Himenoptera \\
Tachinaephagus zealandicus
\end{tabular} & & & A & & & & & & \\
\hline
\end{tabular}

Table 2. Order of arrival of the species with the stages of decomposition at shadowed.

\begin{tabular}{|c|c|c|c|c|c|c|c|c|c|c|c|}
\hline & \multicolumn{11}{|c|}{ Stages of decomposition-Shadowed } \\
\hline & \multirow{2}{*}{\begin{tabular}{|cc}
\multicolumn{3}{c}{ Fresh } \\
15-Feb 16-Feb $17-$-Feb 18-Feb 19-Feb \\
\end{tabular}} & \multicolumn{5}{|c|}{ Bloated } & \multicolumn{5}{|c|}{ Low Decay } \\
\hline & & 20-Feb & 21-Feb & 22-Feb & 23-Feb & 24-Feb & 25-Feb & 26-Feb & 27-Feb & 28-Feb & 01-Mar \\
\hline Diptera & & & & & & & & & & & \\
\hline Phaenicia sericata & & & & & & & L3 & A & & & L3 \\
\hline Cochliomya macellaria & & L2 & L1;L3 & A & L2; L3 & L3 & & L2; L3 & L2;L3 & $\stackrel{\mathrm{L} 1 ; \mathrm{L} 2 ; \mathrm{L}}{3}$ & $\underset{\text { L3;A }}{\text { L1; L2; }}$ \\
\hline Consomyops fulvicrura & & & & & & & & & & & L3;A \\
\hline Chrysomya albiceps & & & & & & & & & & & A \\
\hline Paralucilia pseudolycera & & & & & & & & & & & L2 \\
\hline Sarconesia chlorogaster & & & & & & & & & & & L2 \\
\hline Coleoptera & & & & & & & & & & & \\
\hline Dxyeletrun erythrura & & & & & & & & & & A & A \\
\hline Dermestes maculatus & & & & & & & & & A & A & \\
\hline Himenoptera & & & & & & & & & & & \\
\hline Solenopsis sp & & & A & & & & & & & & \\
\hline Polybia sp (cf scutelaris) & & & A & & & A & & & & & A \\
\hline
\end{tabular}


Table 3. Compared as the states of decomposition and the species present all along the experiment are distributed.

\begin{tabular}{|c|c|c|c|c|}
\hline \multirow[b]{2}{*}{ Day } & \multicolumn{2}{|r|}{ Sunlit } & \multicolumn{2}{|r|}{ Shadowed } \\
\hline & $\begin{array}{c}\text { States of } \\
\text { Decomposition }\end{array}$ & Species & $\begin{array}{c}\text { States of } \\
\text { Decomposition }\end{array}$ & Species \\
\hline $\begin{array}{l}15 \\
16\end{array}$ & Fresh (Fig. 2) & Muscidae & \multirow[b]{3}{*}{ Fresh (Fig. 3) } & \\
\hline 17 & Bloated; lividity & & & \\
\hline 18 & Bloated; lividity & $\begin{array}{l}\text { Adults of Cochliomya macellaria and } \\
\text { Sarconesia chlorogaster. They fed but they } \\
\text { didn't oviposit. Flies in the mouth: C. } \\
\text { macellaria, S. chlorogaster; } 1 \text { Phaenicia } \\
\text { sericata in the nose. Mass of eggs in } \\
\text { packages inside the mouth and some in the } \\
\text { wound, egg }\end{array}$ & & $\begin{array}{l}\text { Muscidae and some Calliphoridae feeding. } \\
\text { No egg masses but loose eggs were } \\
\text { observed in piece of residual fecal matter } \\
\text { (that was retained in the sphincter of the } \\
\text { anus). }\end{array}$ \\
\hline 19 & Bloated; lividity & Mass of eggs in mouth and wound & Bloated; lividity & $\begin{array}{l}\text { Not activity in eyes and ears. In the nose } \\
\text { foamy mucus was observed. The distension } \\
\text { of the stomach caused the expulsion of } \\
\text { residual fecal matter which finally fell to th } \\
\text { ground }\end{array}$ \\
\hline 20 & Rigor mortis. (Fig. 4) & $\begin{array}{l}\text { Larvas in the mouth and the wound. When } \\
\text { turning it they were masses of eggs, on those } \\
\text { that predando ants were. }\end{array}$ & Bloated; lividity. (Fig. 5) & $\begin{array}{l}\text { Larvae in the nose; large number of ants of } \\
\text { the mouth (sample). Swollen to such a point } \\
\text { that hair was marked; with the wire mesh, on } \\
\text { that side still had blood. }\end{array}$ \\
\hline 21 & Bloated & $\begin{array}{l}\text { Immature stadiums of that of mouth and of } \\
\text { the wound }\end{array}$ & Bloated; lividity & $\begin{array}{l}\text { Larvae in the nose. Mucus displaced by } \\
\text { dilation of the abdomen.Causes foum in the } \\
\text { mouth.Mouth full of ants. }\end{array}$ \\
\hline 22 & Odor & $\begin{array}{l}\text { Samples of larvae taken from the mouth and } \\
\text { from of behind the ear that was against the } \\
\text { floor. }\end{array}$ & \multirow{3}{*}{ Rigor mortis } & $\begin{array}{l}\text { Swollen feets didn't cross. Sample of larvae } \\
\text { fron nose. Larvae were not observed in the } \\
\text { wound. }\end{array}$ \\
\hline 23 & \multirow{2}{*}{ Active decay (Fig. 6) } & $\begin{array}{l}\text { Loss of the teeth and ocular globes.Larvae in } \\
\text { mouth and wound. Coleoptera under the } \\
\text { body. Conspicuous activity of Dipteral adults. }\end{array}$ & & Larvae inside the ear and the nose. \\
\hline 24 & & $\begin{array}{l}\text { Cranial bones bare cadaverical fluids. } \\
\text { Inmature instay of Dipteral, Coleoptera adults } \\
\text { and a Hymenoptera }\end{array}$ & & $\begin{array}{l}\text { Very swollen. Larvae inside ear, not observed } \\
\text { elsewhere. (Fig. 7) }\end{array}$ \\
\hline 25 & \multirow{5}{*}{$\begin{array}{l}\text { Skeletal reduction (Fig. } \\
\quad 8 \text { y 10). }\end{array}$} & Cranial bones visible. & \multirow[b]{5}{*}{ Deflated (Fig. 9 y 11). } & $\begin{array}{l}\text { No visible larvae, only a few individuals behind } \\
\text { the ear. Rigid; black discoloration fo trutters } \\
\text { and ears. }\end{array}$ \\
\hline 26 & & $\begin{array}{l}\text { The body of the pig was reduced to the bones } \\
\text { of the front paw, the skull and the ribs that } \\
\text { retaived leather; some larvae were observed }\end{array}$ & & $\begin{array}{l}\text { Little larval activity visible. The abdomen } \\
\text { stayed swollen }\end{array}$ \\
\hline 27 & & Total reduction. Only leather and bones left. & & $\begin{array}{l}\text { Deflated abdomen; sinking of an ocular globe. } \\
\text { Some visible larvae in the mouth, some } \\
\text { Coleoptera and Hymenoptera }\end{array}$ \\
\hline 28 & & $\begin{array}{l}\text { Only bones left. Activity of larvae in vertebral } \\
\text { bodyies }\end{array}$ & & $\begin{array}{l}\text { Hair comes off skin. Adult Coleoptera inside } \\
\text { ear. }\end{array}$ \\
\hline 1 & & Larval activity o ceased entirely & & $\begin{array}{l}\text { Autopsy of the remains: A longitudinal fissure } \\
\text { of about } 6 \mathrm{~cm} \text { long in the thick intestine. Liver, } \\
\text { heart, lungs, preserved and fresh-looking. } \\
\text { Liquid blood inside the abdominal cavity; } \\
\text { larvae not observed. Craniune. Irt was } \\
\text { observed that the right ocular globe was in its } \\
\text { orbit while the left one had collapsed; hard } \\
\text { and soft palate intact, lesion partly number } \\
\text { and ventral of the tongue by ants. Encepahalic } \\
\text { mass diffuse; it was being attacked by larvae } \\
\text { that were collected. Autopsy concluded at the } \\
14 \mathrm{~h} \text {. }\end{array}$ \\
\hline
\end{tabular}


Coleoptera: the most numerous species was Dermestes maculatus (Dermestidae), that appeared with the butyric fermentation stage. The predators Saprinus sp. (Histeridae) and Necrobia rufipes (Cleridae) were found only on the control (sunlit), together with abundant larvae of Diptera. Adult Silphidae (Oxelytrum erythrurum) are predators on large masses of necrophagous larvae for which reason they are considered necrophiles [20] [21].

Species found in the city of Buenos Aires: Dermestes maculatus, D. peruvianus, Anthrenus sp., Necrobia rufipes, N. ruficollis, Oxelytrum erythrurum, and Creophilus maxillosus [22].

Hymenoptera: omnivorous (Leclercq, 1978). Polybia sp. (Vespidae) was observed feeeding upon larvae of Diptera and opon body exudates. Solenopsis sp. (Formicidae) were observed feeding upon larvae and upon the tissues of the pig.

Mallophora sp. (Dipteral, Asilidae) was observed, feeding on the foam in the mouth of the pig, as well as on different exudates of the carcass, thus exploiting an occasional resource of their habitat.

Finally the presence of the parasitoid Tachinaephagus zealandicus (Encyrtidae) was observed on the mass of maggots. The Encyrtidae can be infuid on the PMI evalutation like Turchetto and Vanin discussed in their job [23].

In the shaded carcass, lesions with the aspect of burns due to ants were observed in the dorsal part of the tonge, hard and soft palate. These lesions injure with the marks described by Benecke [24].

\subsection{Oviposition Patterns}

As it has been mentioned, the favorite places for the oviposition are the natural openings of the body, as mouth, eyes, nostrils and ears, and wounds if present.

The patterns of oviposition found were:

1) In the forensic case: nostrils, eyes and mouth (Figure 13).

2) In the present experiment: sunlit carcass: mouth, eyes, ears, wound and genitoanal area. Shaded: eyes, nostrils and ears.

These patterns are comparable with the cases of real death presented by Oliva [19], Goff et.al. [25] and Benecke [26]. Both in the sunlit carcasses and in the shaded one the mouth and the wound were the preferred places for the setting. In the shaded carcass the presence of ants in the mouth may explain that no Diptera larvae have developed there (Table 1, Table 3).

\section{Discussion}

\section{Reconstructed Case}

The shaded carcass reproduced the pattern observed in the entomological sample of the previously mentioned forensic case. Even in summer and outdoors, decay and colonization by insects can take a long time if sunlight is excluded. This justifies the supposition that, in the forensic case, the succession of necrophagous insects was retarded because the body lay among rocks that produced an intense shade (Figure 12). The appearance of Cochliomyia macellaria, is also explained without any assumption that the corpse has been moved, as the three rainy days at the beginning of the experience caused this species to colonize the sunlit carcass in large numbers. This coincides with the interpretation made in the entomology expertise, in which larvae II and III of Cochliomyia macellaria were remarked, and with the hypothesis that there has been a delay induced by the microclimate.

The absence of replicas limits the conclusions to this reconstruction work in particular. The results indicate that the exclusion of sunlight, and also the climate and the topography, can influence in a significant way the processes of decomposition.

The environment is a factor of variation in the behavior of the widespread species, as can be seen by comparing the results in Santa Catalina experiments [11] (nostrils, eyes, ears, mouth, genitoanal region and wound); which also attracted the different stages of decomposition species are compared in two environments different phytogeographic, spinal peri-steppe (Tandil: Central Petrofítico, Santa Catalina: as can be seen in Entrerrianense Center). There is little difference between the two, expressed mainly in the less numerous species of Calliphoridae: C. and P. fulvicrura pseudolyrcea in Tandil; P. cluvia in Santa Catalina.

The volatile compounds of the eucalyptus, as well as those of other vegetal species, extend though the air occupies a bell-shaped space, the form and position of which vary according to the speed and direction of the wind (Quesada-Allué, personal communication). This suggests the interesting possibility that only in certain moments the combination of variables has allowed Diptera to perceive the scent of the carcass. 


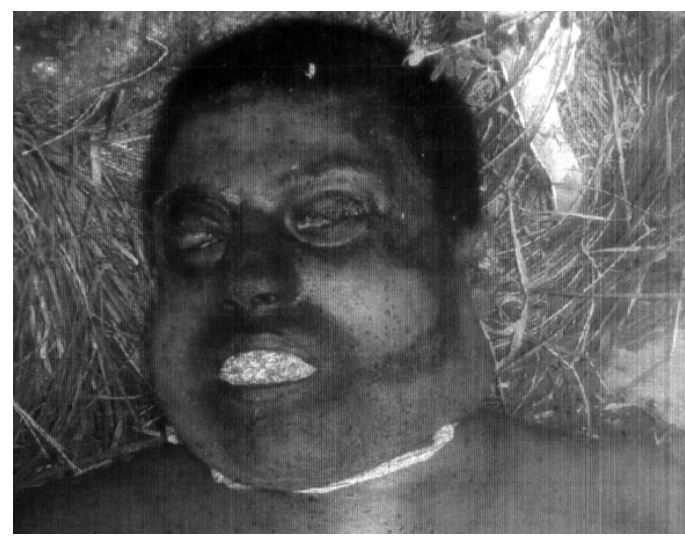

Figure 12. Detail of the face of forensic case.

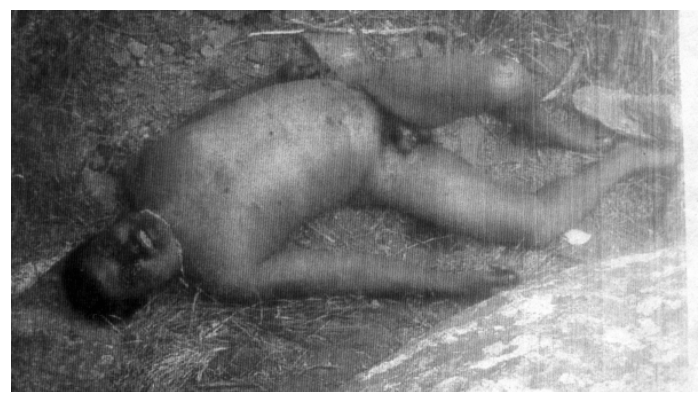

Figure 13. General appearance of forensic case.

Seasonal variations and terpene concentration levels were studied by McClure and Hare (1984) [27]. They found there were variations seasonally and these variations affected insect fecundity. The types of terpenes change with the needs of the tree and the differing levels of monoterpene concentrations, especially of alphapinene, have been found to inhibit and repel insects from attacking trees. High concentration levels were inhibitory and repellent [28] [29] and midlevels caused a synergism with the insect being able to bore into the tree and construct galleries [28].

Pheromones are chemical cues, which are emitted and received by the same species of insect in communicating with each other. Terpene-pheromone ratios have an affect on insect response. Inhibiting insect attraction to pheromones is a tree defense factor. However, once colonization has occurred and resin levels are used up, a low alpha-pinene to pheromone ratio causes a reduction in attraction thereby controlling insect populations to prevent overcrowding [29]. Monoterpenes can either attract or inhibit attraction to an insect's response to its aggregation pheromone. The trees response to attack and wounding changes the monoterpene concentration levels [30]. It would be interesting to follow up this subject in successive experiments.

The present experiment has shown that the colonization by C. macellaria may take place outdoors, with the condition that the environmental conditions exclude to the pure primary species. It has also been verified that in the climate of Tandil, the shade generated by characteristic topographical, it is enough to affect the succession of necrophagous insects.

\section{Acknowledgements}

I thank Dr. Alejandro Soraci, Dean of the Universidad Nacional del Centro de la Provincia de Buenos Aires, Facultad de Ciencias Veterinarias, Tandil, for authorization to use the experimental farm "La Chacra" for the present work. Commissary Yeffal of the sectional No. 2 of Tandil and to the Dra. Person of the U.F.I. No. 3 of Tandil, for granting access access to the cause. Laboratory of Forensic Etomology of Museo Argentino de Ciencias Naturales to lend the laboratory for the determinations. To that special person that has been always at my side, giving energy and company, and prefers his name not tribe mentioned, thank you, "Rex" and Gina for being always there. 


\section{References}

[1] Goff, M.L. (1998) Determination of Time since Death in the Early Postmortem Period. International Seminar in Forensic Entomology, Bari, 12-14 November 1998, 1-16.

[2] O’Flynn, M.A. (1993) The Succession and Rate of Development of Blowflies in Carrion in Southern Queensland and the Application These Data to Forensic Entomology. Journal of the Australian Entomological Society, 22, 137-148. http://dx.doi.org/10.1111/j.1440-6055.1983.tb01860.x

[3] Mann, R.W., Bass, W.M. and Meadows, L. (1990) Times since Death and Decomposition of the Human Body: Variables and Observations in Case and Experimental Field Studies. Journal of Forensic Sciences, 35, 103-111.

[4] Shean, B.S., Messinger, L. and Papworth, M. (1993) Observation of Differential Decomposition on Sun Exposed v. Shaded Pig. Carrion in Coastal Washington State. Journal of Forensic Sciences, 38, 938-949.

[5] Tantawi, T.I., El-Kady, E.M., Greenberg, B. and El-Ghaffar, H.A. (1989) Arthropod Succession on Exposed Rabbit Carrion in Alexandria, Egypt. Journal of Medical Entomology, 33, 566-580.

[6] Tripathi, A.K., Prajapati, V., Aggarwal, K.K. and Kumar, S. (2001) Toxicity, Feeding Deterrence, and Effect of Activity of 1,8-Cineole from Artemisia annua on Progeny Production of Tribolium castanaeum (Coleoptera: Tenebrionidae). Journal of Economic Entomology, 94, 979-983. http://dx.doi.org/10.1603/0022-0493-94.4.979

[7] Anderson, G.S. (1999) Wildlife Forensic Entomology: Determining Time of Death in Two Illegally Killed Black Bears Cubs. Journal of Forensic Science, 44, 856-859.

[8] Martínez, E.T. and Rudelir, M. (2004) Complicaciones psiquiátricas del uso indebido de la cocaína: Aspectos MédicoLegales. Cuaderno de Medicina Forense, 3, 67-72. http://www.csjn.gov.ar/cmfcs/cuadernos/pdf/vol3_2_2004/09.pdf

[9] Martínez, E.T. and Rudelir, M. (2005) Trastornos por uso de Marihuana: Aspectos Médico-Legales. Cuaderno de Medicina Forense, 4, 7-18. http://www.csjn.gov.ar/cmfcs/cuadernos/pdf/vol4_1_2005/Toro_Martinez.pdf

[10] Centeno, N.D. and Maldonado, M. (2002) Entomofauna cadavérica asociada a cuerpos encerrados. In: Simposio de Entomología Forense. Resúmenes del V Congreso Argentino de Entomología, Buenos Aires, 434.

[11] Centeno, N.D. (2002) Experimentos de campo sobre sucesión de Fauna cadavérica. In: Simposio de Entomología Forense. Resúmenes del V Congreso Argentino de Entomología, Buenos Aires, 67-69.

[12] Lewis, J.P. and Collantes, B.M. (1973) El espinal periestépico. Ciencia e Investigación, 29, 360-377.

[13] Giamakis, A., Kretsi, O., Chinou, I. and Spyropoulos, C.G. (2001) Eucalyptus camaldulensis: Volatiles from Immature Flowers and High Production of 1,8-Cineole and $\beta$-Pinene by in vitro Cultures. Phytochemistry, 58, 351-355. http://dx.doi.org/10.1016/S0031-9422(01)00193-5

[14] Pappas, R.S. and Sheppard-Hanger, S. (2000) The Essential Oil of Eucalyptus camaldulensis Dehn. From South Florida: A High Cryptone/Low Cineole Eucalyptus. Journal of Essential Oil Research, 12, 383-384. http://dx.doi.org/10.1080/10412905.2000.9699541

[15] Greenberg, B. and Szyska, M.L. (1984) Immature Stages and Biology of Fifteen Species of Peruvian Calliphoridae (Diptera). Annals Entomology of the Society of America, 77, 488-517.

[16] Liu, D. and Greenberg, B. (1989) Immature Stages of Some Flies of Forensic Importance. Annals of the Entomological Society of America, 82, 80-93.

[17] Mariluis, J.C. and Schnack, J.A. (2002) Calliphoridae de la Argentina. Sistemática, ecología e importancia sanitaria (Diptera, Insecta). Actualizaciones en artropología sanitaria argentina. RAVE (Red Argentina de Estudios de Artrópodos Vectores de Enfermedades Humanas). Serie: Enfermedades Transmisibles. Publicación Monográfica 2, 23-37.

[18] Oliva, A. (2002) Diptera (Insecta) de interes forense o causantes de miasis. Claves artificiales para estadíos preimaginales. Actualizaciones en artropología sanitaria argentina. RAVE (Red Argentina de Estudios de Artrópodos Vectores de Enfermedades Humanas). Serie: Enfermedades transmisibles. Publicación Monográfica 2, 51-60.

[19] Laake, E.W., Cushing, E.C. and Parish, H.E. (1936) Biology of the Primary Screwworm Fly. Cochliomyia americana, and a Comparison of Its Stages with Those of C. macellaria. US Department of Agriculture Technical Bulletin, 500, 24.

[20] Oliva, A. (1997) Insectos de interés forense de Buenos Aires (Argentina). Primera lista ilustrada y datos binómicos. Revista del Museo Argentino de Ciencias Naturales "Bernardino Rivadavia” e Instituto Nacional de Investigación de las Ciencias Naturales, Entomología, VII, 14-59.

[21] Leclerq, M. (1978) Entomologie et médicine Légale. Datation de la mort. Collection de Médicine Légale et de Toxicologie Médicale, no. 108. Masson, Paris, 1-100.

[22] Oliva, A. (2001) Insects of Forensic Significance in Argentina. Forensic Science International, 120, 145-154. http://dx.doi.org/10.1016/S0379-0738(01)00423-6 
[23] Turchetto, M. and Vanin, S. (2004) Forensic Evaluations on a Crime Case with Monospecific Necrophagous Fly Population Infected by Two Parasitoid Species. Anil Aggrawal's Internet Journal of Forensic Medicine and Toxicology, 5, 12-18.

[24] Benecke, M. (2001) A Brief History of Forensic Entomology. Forensic Science International, 120, 2-14. http://dx.doi.org/10.1016/S0379-0738(01)00409-1

[25] Goff, M.L., Olmi, A.I. and Goodbrod, J.R. (1989) Effect of Cocaine in Tissues on the Development Rate of Boettcherisca peregrina (Diptera: Sarcophagidae). Journal of Medical Entomology, 26, 91-93.

[26] Benecke, M. (1998) Six Forensic Entomology Cases: Description and Commentary. Journal of Forensic Sciences, 43, 797-805.

[27] McClure, M.S. and Hare, J.D. (1984) Foliar Terpenoids in Tsuga Species and the Fecundity of Scale Insects. Oecologia, 63, 185-193. http://dx.doi.org/10.1007/BF00379876

[28] Wallin, K.F. and Raffa, K.F. (2004) Feedback between Individual Host Selection Behavior and Population Dynamics in an Eruptive Herbivore. Ecological Monographs, 74, 101-116. http://dx.doi.org/10.1890/02-4004

[29] Erbilgin, N., Powelll, J.S. and Raffa, K.F. (2003) Effect of Varying Monoterpene Concentrations on the Response of Ips pini (Coleoptera: Scolytidae) to Its Aggregation Pheromone: Implications for Pest Management and Ecology of Bark Beetles. Agricultural and Forest Entomology, 5, 269-274. http://dx.doi.org/10.1046/j.1461-9563.2003.00186.x

[30] Erbilgin, N. and Raffa, K.F. (2000) Opposing Effects of Host Monoterpenes on Responses by Two Sympatric Species of Bark Beetles to Their Aggregation Pheromones. Journal of Chemical Ecology, 26, 2527-2548. http://dx.doi.org/10.1023/A:1005532612117 